\title{
Chapter 5 \\ Small Coastal Island Ecosystems \\ and Conservation Perspectives Within Adaptation Efforts
}

\author{
Dietriech Geoffrey Bengen
}

\subsection{Introduction}

Indonesia, which consists of 16,671 named islands and 104,000 km of coastline, is the biggest archipelagic state and a host to precious and essential coastal and small island goods and services.

While perceiving the extensive mangrove forests and vast coral reefs along the coasts of more than 10,000 small scattered islands from Aceh to Papua of the Indonesian archipelago, how many people stop appreciating the role of those ecosystems in human lives? These two primary coastal-small island ecosystems highlight strategic values for human lives. Mangroves and coral reefs perform four essential functions: (1) provide useful natural resources, (2) support essential services for human livelihood, (3) maintain leisure services, and (4) protect coastal areas from natural disasters. Small coastal island ecosystems contain various natural resources, which are essential for human lives and daily livelihood. As a support system for critical human services, Small coastal island ecosystems provide a clean environment to support human activities, in addition to providing aesthetic tourism sites and protection from numerous natural disasters that threaten coastal and small island areas (Bengen 2020).

Thus, referring to the four integral ecosystem functions, coastal areas, and the thousands of small islands in Indonesia is challenging and promising. Small coastal islands should not merely be exploited for their natural resources; they should also be placed at the center of human welfare and different forms of utilization, e.g., ports and transportation hubs, marine-based industry, and community housing. A survey of research and literature showed that at least $85 \%$ of marine species are connected in some way to small coastal island ecosystems at some stage in their life

D. G. Bengen $(\bowtie)$

Faculty of Fisheries and Marine Science, IPB University, Bogor, Indonesia

e-mail: dieter@indo.net.id 
cycle, and about $90 \%$ of fisheries yields originated from small coastal island ecosystems (FAO 2000).

Unfortunately, extensive damage has occurred to small coastal island ecosystems, not only threatening the natural capacity of the small coastal island in restoring their resources but reducing their capacity to mitigate natural disasters and exposing their vulnerabilities. Impacts include the loss of spawning habitats, degradation of nurseries and foraging areas for various species, and reductions in fish stocks. Further impacts include the loss of coastal ecosystems' physical functions, such as erosion prevention, wave reduction, seawater intrusion prevention, and waste absorption. Ecosystem damage originated from destructive practices associated with exploiting natural resources and nonenvironmentally friendly development in the small coastal island areas, e.g., blast fishing, extensive mangrove clearance, habitat alteration, and coral reef mining. Destruction of small coastal island ecosystems will lead to more adverse impacts when climate change impacts are considered. To restore valuable small coastal island ecosystem functions and services, particularly vital services for disaster mitigation, coastal-small island ecosystem protection and rehabilitation efforts should be undertaken in previously degraded areas.

\subsection{Threats Related to Climate Change to Coastal-Small Island Ecosystems}

As the interface between the terrestrial and marine ecosystems, small coastal islands are highly dynamic environments continually changing over relatively short periods. Typically, these dynamics are at equilibrium, but any significant change can negatively impact large and complicated ramifications. The increase in atmospheric greenhouse gas (GHG) emissions has changed the climate, warming air and sea surface temperatures, and increasing ocean acidification due to $\mathrm{CO}_{2}$ diffusion into the ocean. Further heating may change rainfall patterns, causing sea level rise (SLR) and extreme weather events, like tropical cyclones (Anonymous 2008). Tangible consequences of climate change on small coastal island ecosystems include a rising sea surface, changes in seawater alkalinity, alterations in ocean circulation, localized upwelling due to vertical changes in seawater properties, sea-level rise, and increased frequency of extreme storm events, high tides, and heavy precipitation (Alongi 1998).

Regarding sea level rise, the last assessment by Working Group I of IPCC in February 2007 (IPCC 2007) showed that the sea level has risen by an average of $2.5 \mathrm{~mm}$ annually, and it was predicted to rise by $31 \mathrm{~mm}$ over the next decade. Indonesia, an island nation with over 10,000 small islands and 104,000 km of coastline, is very vulnerable to SLR. If SLR continues, Indonesia may lose as many as 2000 low-lying islands, including small coastal island ecosystems, by 2030 (Ministry of Environment of Republic of Indonesia 2007). Additionally, an SLR of 
between 8 and $30 \mathrm{~cm}$ by 2030 is likely to severely impact small coastal island ecosystems (PEACE, DFID, and World Bank 2007).

\subsection{Importance of Established Conservation Areas for Adaptive Measures of Small Coastal Islands Towards Climate Change}

There are responsive and planned adaptations to climate change. Responsive adaptations refer to changes in policy and behavior that people and organizations adopt in response to inevitable climate change and coastal and small island risks. Planned adaptation is intentional, proactive, and occurs at the societal level. It is more strategic than responsive adaptation and can address the full range of climate change hazards in coastal and small island resources in ways that meet social objectives.

Mainstreaming adaptation into the national development plan provides a strategy for planned adaptations in coastal and small island areas that highlighted actions that sought to "protect," "accommodate," and "retreat" from climate change impacts. While these approaches can be useful, coastal and marine adaptation has evolved to include a more integrated approach that incorporates ecosystem management and sustainable development.

The following types of adaptative actions could contribute to four outcome goals: (1) functioning and healthy coastal and marine ecosystems, (2) living shorelines, (3) reduced exposure and vulnerability of the built environment, and (4) strengthened capacity for adaptation.

In Indonesia, small coastal island areas include promising natural resources and environmental services, which are well suited to Indonesian sustainable marine development. The ever-increasing threat of climate change to small coastal islands, as previously described, intensifies ecosystem and natural resources degradation, including habitat degradation and biodiversity loss. Therefore, adaptive measures are required to mitigate climate change and protect ecologically and economically significant resources and maintain ecosystem integrity.

One adaptation to climate change impacts is establishing and developing coastal and small island conservation areas. Designated conservation areas should comprise intertidal to subtidal zones and the various associated flora and fauna with ecological, economic, social, and cultural values.

The main target of conservation in small coastal islands is the existing ecosystem and natural resources, and the aim is to maintain ecological processes, resource production, and environmental services for a sustainable human livelihood (Agardy 1997). Regarding the limited capacity of natural resources in small coastal island habitats, it is necessary to implement specific management schemes incorporating different types of users to ensure that the adaptive measures maintain these habitats' functional priorities. In this context, coastal-small island ecosystems bear intricate 
composition and dynamics between biophysical, social, and economic sub-system, which take place in the transitional landscape.

Small coastal island ecosystems are typically comprised of inter-related systems with particular landscape and time domains. Different traits of the biophysical, social, and economic systems in one landscape can affect one another. Thus, each spatial scheme may feature synergistic or conflicting interactions.

Ecosystem-based conservation management deals with managing different activities to utilize coastal-small island ecosystems. In the end, the increasing use of small coastal island resources should not exceed the natural functional capacity. Every natural ecosystem has four essential functions for humans: (1) providing useful natural resources, (2) support essential services for human livelihood, (3) maintain leisure services, and (4) protecting humans from hazardous natural disasters (Ortolano 1984). The first two functions are closely associated with the latter two functions. Thus, the natural ecosystem's second two functions keep working whenever the first two functions are preserved.

Within the framework of ecology, there are three prerequisites for accomplishing the optimum and sustainable management of small coastal island conservation areas: (1) spatial harmony, (2) assimilation capacity, and (3) sustainable use (Bengen 2002). Spatial harmony requires applying three different zones within one conservation area: preservation (no-take) zone, buffer zone, and the use zone (Fig. 5.1). Therefore, incorporating space within the conservation area should include a space protected from extraction activities (no-take zone). The ideal case for a preservation (no-take) zone would be for uses such as spawning grounds and coastal green belts, which usually serve as nurseries. In this preservation (no-take) zone, apart from scientific research and educational activities, other types of activities are prohibited. Different types of regulated exploitation activities, like fisheries and tourism, are permitted and limited exploitation activities in the use zone's buffer zone.

The preservation zone and the buffer zone in one conservation area are essential for maintaining different processes, which support sustainable resource production-for example, hydrologic and nutrient cycling, natural waste recycling, and biodiversity preservation. Furthermore, any exploitation activities (fisheries and mariculture) in the use zone should be managed to maintain biophysical harmony. Any exploitation activities in the utilization zone must consider several variables, such as (1) suitability of different uses to a particular existing ecosystem, (2) impacts associated with coastal activities and land-based activities (e.g., pollution, sedimentation, alternating hydrological regimes), as well as climate change-related impacts, and (3) compatibility between different utilization activities.

One of the small coastal island conservation strategies currently being developed as an adaptation measure in small coastal island ecosystems is a Marine Protected Area (Marine Sanctuary). The development of marine protected areas is done in order to maintain and improve the quality of small coastal island ecosystems and, at the same time, maintain and improve the quality of other marine living resources associated with the coastal-small island ecosystems. The objectives of marine protected areas are: (1) maintaining ecological functions by protecting habitats for living and spawning marine biota, and (2) maintaining the economic function of small 


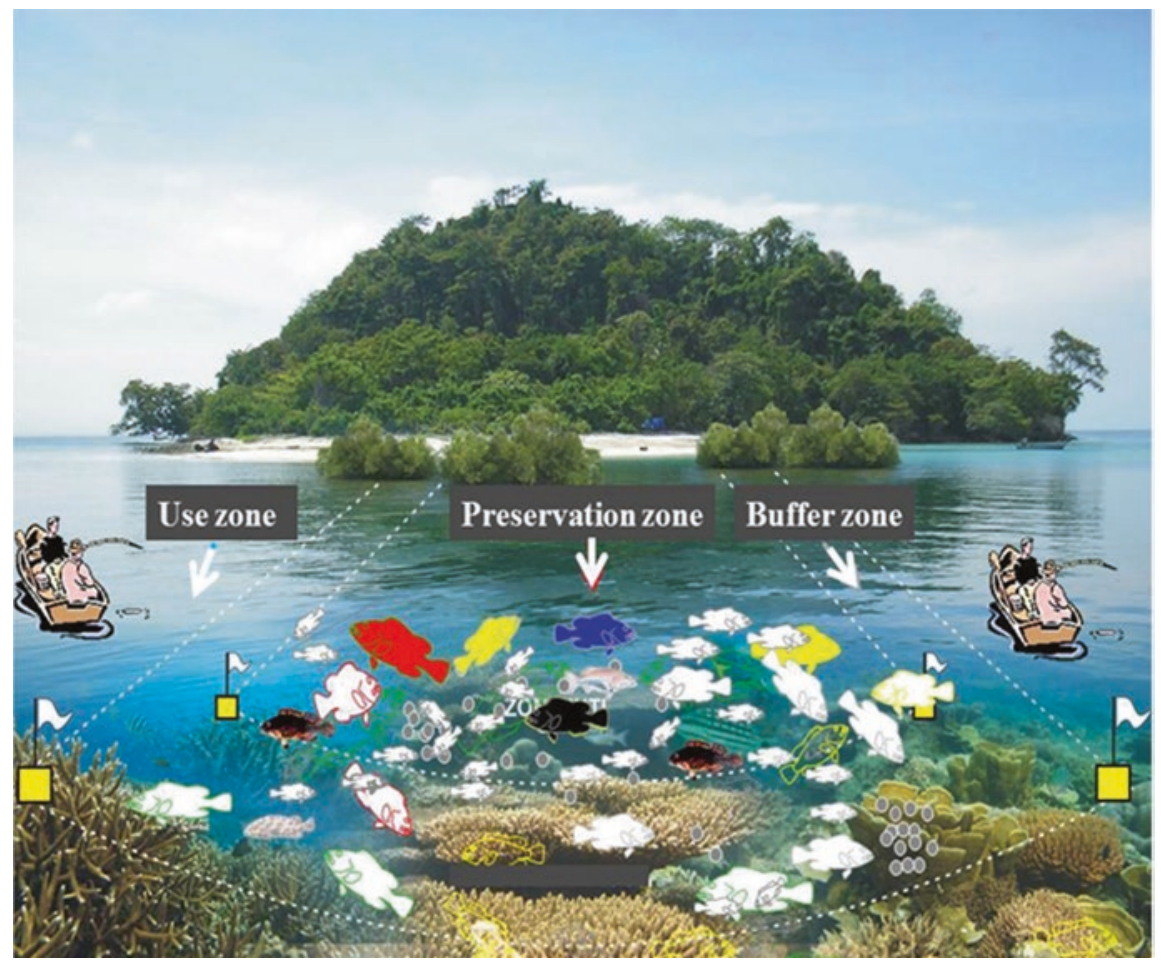

Fig. 5.1 Zonation of the small coastal island conservation area

coastal island ecosystems for local communities and their surroundings so that the sustainability of fishery production can be maintained and so that people's income will increase (Bengen et al. 2003; Faiza et al. 2010).

Figure 5.2 shows that the community's marine protected area (DPL) of Sebesi Island is divided into two zones: the core and buffer zones, in which the respective provisions apply. However, these activities are intended to protect marine resources, which the community will use to meet their daily needs (increased fish production). The prohibition on fishing gear in marine protected areas prevents damage to the small coastal island ecosystems and increases the fish resources associated with these small coastal island ecosystems. Utilization is only performed in a limited manner and uses simple non-destructive tools; further, it is carried out at a particular time, namely when the fishery has recovered. When the marine protected area has not been able to support the life of the coastal community of Sebesi Island, the social system of the Sebesi Island community seeks to find energy sources (alternative livelihoods) to meet their needs. It is done to prevent the removal of energy sources from the marine protected area. Therefore, some community members (system components) carry out marine cultivation activities or look for fish in places outside the marine protected areas to meet their daily needs (Bengen et al. 2003). 


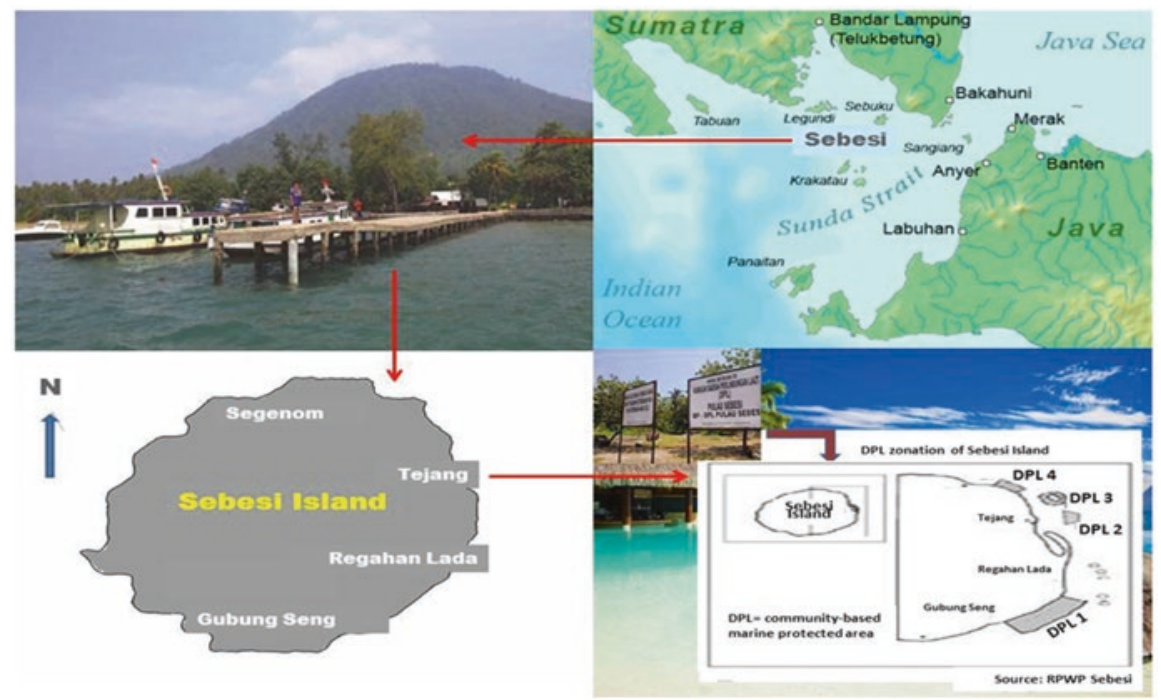

Fig. 5.2 Community-based marine protected area (DPL) of Sebesi Island, Lampung

As featured in a coastal-small island conservation area about various existing ecosystems, complexity indicates the urgency of integrated management in applied to corroborate adaptive measures to climate change impacts.

\subsection{Lessons Learned}

With the potential impact of climate change on the coastal-small islands, conservation areas' establishment and development are an adaptation strategy that protects small island ecosystems from damage due to climate change.

Small island coastal conservation measures require the assistance of both national and local governments, particularly in the following areas:

- technical assistance and funding mechanisms for local government in coastal resource management

- funding assistance criteria for local government

- incentives and disincentives

- commitments of both local and national government in sustainable coastal and marine resources management

Sustainable small coastal island conservation management requires thorough and participatory planning. It calls for coastal and marine resources management policies and strategies at national and local levels.

Prerequisites for small island coastal conservation management to be sustainable include initiatives that are: 
- in concordance with formal and informal local policies

- inline with local communities' social and cultural conditions

- supported by human resources and institutional capacities

- have the involvement stakeholders

- a clear plan and program

- positive impacts on the environment, including local communities' socio-cultural and economic conditions.

For small island coastal conservation programs to have a widespread impact, careful consideration needs to be given to conservation replication design. The design requirement will include:

- a complete set of data and information (documentation process)

- evaluation of program relevance to conditions of particular areas

- evaluation of program impacts on the environment and communities

- involvement of stakeholders and communities in planning

- dissemination of information strategies.

Integrated small island coastal conservation management is one of the requirements to achieve optimal and sustainable management.

\section{References}

Agardy TS (1997) Marine protected areas and ocean conservation. Academic, San Diego

Alongi DM (1998) Coastal ecosystem processes. CRC Press LLC

Anonymous (2008) Adapting to coastal climate change. United States Agency for International Development

Bengen DG (2002) Coastal resources and ecosystems and its integrated and sustainable management. Marine Journalist Training Paper, organized by WWF-Wallacea Program, Bali, April 9-11, 2002

Bengen DG (2020) Integrated coastal zone management for coastal-small island ecosystem resilience in the face of climate crisis. Proceeding of the international workshop (Natural resource and risk management in the context of climate change: Southeast Asia Research-based Network on Climate Change Adaptation Science), Hanoi, January 9-10, 2020

Bengen DG, Tahir A, Wiryawan B (2003) Tinjauan Sustainabilitas, Akuntabilitas, Replikabilitas Pengembangan Daerah Perlindungan Laut di Pulau Sebesi, Lampung Selatan, Provinsi Lampung. Proyek Pesisir, Jakarta

Faiza R, Kusumastanto T, Bengen DG, Boer M, Yulianda F (2010) Sustainability of communitybased marine protected area (case study: Blongko village, North Sulawesi, Sebesi Island, Lampung and Harapan Island, Jakarta). J Bijak dan Riset Sosek KP 5(1):19-30. (in Indonesian)

FAO (2000) The status of world fisheries and aquaculture. FAO Fisheries Department, Rome

IPCC (2007) Climate Change 2007: impacts, adaptation, and vulnerability. In: Parry ML, Canziani OF, Palutikof JP, van der Linden PJ, Hanson CE (eds) Contribution of Working Group II to the Fourth Assessment Report of the Intergovernmental Panel on Climate Change. Cambridge University Press, Cambridge

Ministry of Environment of Republic of Indonesia (2007) Climate variability and climate changes, and their adaptation. Ministry of Environment of the Republic of Indonesia, Jakarta

Ortolano L (1984) Environmental planning and decision making. Wiley, Toronto

PEACE, DFID, World Bank (2007) Indonesia and Climate Change status and policies. PEACE, DFID, and the World Bank 
Open Access This chapter is licensed under the terms of the Creative Commons Attribution 4.0 International License (http://creativecommons.org/licenses/by/4.0/), which permits use, sharing, adaptation, distribution and reproduction in any medium or format, as long as you give appropriate credit to the original author(s) and the source, provide a link to the Creative Commons license and indicate if changes were made.

The images or other third party material in this chapter are included in the chapter's Creative Commons license, unless indicated otherwise in a credit line to the material. If material is not included in the chapter's Creative Commons license and your intended use is not permitted by statutory regulation or exceeds the permitted use, you will need to obtain permission directly from the copyright holder. 